DOI: $10.19195 / 0524-4544.325 .6$

MATEUSZ SZYMURA

ORCID: 0000-0001-7146-8477

Uniwersytet Wrocławski

mateusz.szymura@uwr.edu.pl

\title{
Spoliatus ante omnia restituendus est. Spuilzie jako szkocka metoda restytucji utraconego posiadania
}

\section{Wstęp}

Tradycyjne postrzeganie szkockiego systemu prawa prywatnego jako hybrydowego systemu prawnego zakłada przedstawienie owego systemu jako specyficznego amalgamatu elementów opartego na prawie rzymskim kontynentalnej tradycji prawnej oraz rozwiązań o anglosaskim pochodzeniu. Owa koncepcja, skupiając się na zasadniczych różnicach między oboma podstawowymi tradycjami prawnymi, zdaje się czasem traktować je jako twory o charakterze homogenicznym, zapominając zarówno o bogactwie modelów rozwiązań prawnych, które stanowią element wspomnianych tradycji, jak i o sporach doktrynalnych, które je kształtują.

\section{O dwóch koncepcjach posiadania}

Jedną $\mathrm{z}$ istotnych kontrowersji istniejących $\mathrm{w}$ ramach tradycji prawa cywilnego, która wpływa na kształt dyskusji także w szkockiej nauce prawa, jest problem natury posiadania oraz kwestia charakteru wolicjonalnego elementu posiadania (animus).

Athanassios Yiannopoulos wskazał, że ów problem rozwiązywany jest na podstawie jednej z dwóch koncepcji: subiektywnej teorii posiadania stworzonej 
przez Friedricha Carla von Savigny'ego ${ }^{1}$, która kładła nacisk na wewnętrzne przekonania podmiotu, iż dzierży rzecz bądź dla siebie, bądź w imieniu innej osoby, z obiektywną teorią posiadania, autorstwa Rudolfa von Iheringa ${ }^{2}$, która akcentuje tytuł prawny, czyli przyczynę uzyskania władztwa nad rzeczą ${ }^{3}$.

Ta linia podziału wyraźnie wpływa na charakter regulacji posiadania w poszczególnych ustawodawstwach oraz zakres legitymacji w wypadku roszczeń restytucyjnych w sytuacji bezpodstawnego wyzucia z posiadania. Francuskie ustawodawstwo bliższe jest teorii Savigny'ego, uznaje bowiem animus rem sibi habendi jako konieczny element posiadania ${ }^{4}$, jednocześnie zapewniając ochronę posesoryjną także detentorom, choć jest to ochrona jedynie względnie skutecz$\mathrm{na}^{5}$. Tymczasem na rozwiązania niemieckie silnie wpłynęła koncepcja Iherninga, w której to nie zamiar, a podstawa (causa) stanowi źródło dystynkcji między posiadaniem a dzierżeniem ${ }^{6}$, co pozwala na uznanie podmiotów klasycznie określanych jako detentorzy za posiadaczy ${ }^{7}$, a w konsekwencji przyznanie im na równi z posiadaczami sensu stricto uprawnienia do wniesienia powództwa restytucyjnego jako ich własnego uprawnienia, skutecznego w niektórych sytuacjach także przeciwko właścicielowi rzeczy ${ }^{8}$.

${ }^{1}$ Friedrich Carl von Savigny (1779-1861) — niemiecki prawnik i historyk, przedstawiciel historycznej szkoły prawa, stojącej w opozycji zarówno wobec koncepcji pozytywizmu prawniczego, jak i iusnaturalizmu, która akcentowała, iż prawo jako fenomen stanowi element kultury narodowej, którego nie można stworzyć w wyniku działania sztucznego, jakim jest kodyfikacja, a jedynie poprzez jego ewolucyjny rozwój zgodnie z podłożem społecznym i duchem narodu.

2 Rudolf von Ihering (1818-1892) - niemiecki prawnik i znawca prawa rzymskiego, przedstawiciel pozytywizmu prawniczego, uznawany za twórcę jurysprudencji socjologicznej.

3 A.N. Yiannopoulos, Possession, „Louisiana Law Review” 51, 1991, s. 523-524.

4 Artykuł 2255 francuskiego Kodeksu Cywilnego w brzmieniu z 17 czerwca 2008 roku (Code Civil, dalej: CC): „La possession est la détention ou la jouissance d'une chose ou d'un droit que nous tenons ou que nous exerçons par nous-mêmes, ou par un autre qui la tient ou qui l'exerce en notre nom".

5 Artykuł 2283 CC: „La possession est protégée, sans avoir égard au fond du droit, contre le trouble qui l'affecte ou la menace. La protection possessoire est pareillement accordée au détenteur contre tout autre que celui de qui il tient ses droits".

${ }^{6} \S 854$ niemieckiego Kodeksu Cywilnego (Bürgerliches Gesetzbuch, dalej: BGB):

„(1) Der Besitz einer Sache wird durch die Erlangung der tatsächlichen Gewalt über die Sache erworben.

(2) Die Einigung des bisherigen Besitzers und des Erwerbers genügt zum Erwerb, wenn der Erwerber in der Lage ist, die Gewalt über die Sache auszuüben".

7 § 868 BGB: „Besitzt jemand eine Sache als Nießbraucher, Pfandgläubiger, Pächter, Mieter, Verwahrer oder in einem ähnlichen Verhältnis, vermöge dessen er einem anderen gegenüber auf Zeit zum Besitz berechtigt oder verpflichtet ist, so ist auch der andere Besitzer (mittelbarer Besitz)."

$8 \S 861$ BGB, zdanie pierwsze: (1) ,Wird der Besitz durch verbotene Eigenmacht dem Besitzer entzogen, so kann dieser die Wiedereinräumung des Besitzes von demjenigen verlangen, welcher ihm gegenüber fehlerhaft besitzt". 


\section{Szkocka debata o naturze posiadania}

Raffaele Caterina ${ }^{9}$ wskazuje, że owa debata ma miejsce również w ramach szkockiej nauki prawa ${ }^{10}$. O ile David Carrey Miller ${ }^{11}$ opowiada się za zastosowaniem doktryny Savigny'ego i uznaniem atrybutu animo domini za warunek sine qua non uznania podmiotu za posiadacza, o tyle Kenneth Reid ${ }^{12}$ uznaje zasadność przyznania odrębnej ochrony posesoryjnej również takiej osobie, która posiadanie wykonuje na podstawie umowy z jej właścicielem.

Owa odmienność poglądów w szkockiej doktrynie prawnej ma długą tradycję, już bowiem pisarze instytucjonalni ${ }^{13}$ mieli odmienne wizje dotyczące problemu natury posiadania. Stair ${ }^{14}$ opowiada się za klasycznym dualizmem elementu władztwa fizycznego i postawy wolicjonalnej względem rzeczy, które są mani-

9 R. Caterina, Concepts and remedies in the law of possession, „Edinburgh Law Review” 8, 2004, s. 267.

${ }^{10} \mathrm{~W}$ niniejszym opracowaniu zostaną wykorzystane następujące szkockie traktaty prawnicze (w kolejności chronologicznej, według pierwszych wydań): Institutions of the Law of Scotland (Edinburgh 1681) Jamesa Darlymple'a, wicehrabiego Staira (dalej: Stair), Institutes of the Law of Scotland in Civil Rights (Edinburgh 1751-1753) Andrew MacDoualla, lorda Banktona (dalej: Bankton) oraz dzieło Johna Erskine'a z Carnock — The Institute of the Law of Scotland (Edinburgh 1773) (dalej: Erskine). Dzieła cytowane są według układu treści: księga — tytuł — fragment.

11 D.L. Carrey Miller, Corporeal Moveables in Scots Law, Edinburgh 1991, s. 12.

12 K.G.C. Reid, The Law of Property in Scotland, Edinburgh 1996, s. 108.

13 Jako pisarzy instytucjonalnych określa się tych przedstawicieli szkockiej jurysprudencji, których traktaty prawnicze w ocenie przedstawicieli judykatury uzyskały status subsydiarnego źródła prawa. Ich wyjątkowy charakter wynikał z faktu wypełnienia istotnych luk w szkockim prawie prywatnym oraz stosunkowo dużej żywotności dzieł — szkocki system prawny ani w XIX wieku, ani później nie doczekał się bowiem kompleksowej kodyfikacji prawa prywatnego. Znaczenie dzieł opierało się na wadze, jaką wyrażonym w nich opiniom autorów przypisywali ówcześni oraz późniejsi prawnicy - teoretycy i praktycy — stosując je jako przedmiot wykładu czy uzasadnienie wyroków. Dzieła instytucjonalne powstały w określonym momencie historycznym jako odpowiedź na potrzebę wykształcenia się odrębnego i nowoczesnego systemu szkockiego prawa prywatnego. Historia w ten sposób zatoczyła więc koło — dzieła instytucjonalne, które sprowadziły do roli pomników prawa źródła prawa z okresu średniowiecznego, same w toku XX oraz XXI wieku uzyskały taki status w wyniku swojej dezaktualizacji przez utrwalenie się precedensowego charakteru szkockiego sądownictw. Zob. szerzej J.W. Cairns, Institutional Writings in Scotland Reconsidered, [w:] New Perspectives in Scottish Legal History, red. A. Kiralfy, H.L. MacQueen, London 1984; K. Luig, The Institutes of National Law in the Seventeenth and Eighteenth Centuries, „Juridical Review” 17, 1972, s. 193-226.

14 James Darlymple, wicehrabia Stair (1619-1696) — szkocki adwokat, nauczyciel akademicki, lord prezydent Sądu Sesji oraz twórca jednego z podstawowych szkockich traktatów prawniczych: The Institutions of the Law of Scotland, deduced from its Originals and collated with the Civil, Canon and Feudal Laws and with the Customs of neighboring Nations (Edinburgh 1681). Wskazane dzieło doczekało się sześciu edycji (ostatniej w 1981 roku). Dot Reid uważa, że praca Staira stanowi najistotniejsze wydarzenie w rozwoju szkockiego prawa prywatnego, a twierdzenia przedstawione w pracy — choć w znacznym zakresie dziś już nieaktualne - są obowiązujące ze względu na znaczenie, jakie przypisują im sądy i doktryna prawna. Zob. szerzej Thomas Aquinas 
festowane przez posiadacza, a które mają je odróżniać od samego dzierżenia. Za najważniejszy element wyróżniający posiadanie od innych form fizycznego dzierżenia rzeczy uznaje wolę posiadania rzeczy dla siebie lub też wolę posiadania rzeczy przez inną osobę, lecz w imieniu posiadacza ${ }^{15}$. Dla kontrastu, Erskine ${ }^{16}$ większy nacisk kładzie na podstawę prawną posiadania, wskazując, iż posiadanie składa się po części z faktu, a po części z tytułu prawnego do rzeczy ${ }^{17}$.

\section{Geneza spuilzie jako powództwa restytucyjnego}

Przedmiotem niniejszego opracowania jest próba zweryfikowania obu poglądów oraz wskazania obowiązującej na gruncie systemu szkockiego prawa prywatnego koncepcji posiadania, oparta na przedstawieniu specyfiki szkockiego powództwa restytucyjnego - spuilzie $e^{18}$, na podstawie analizy poglądów najważniejszych przedstawicieli szkockiej jurysprudencji w okresie od końca XVII do pierwszej połowy XIX wieku, których prace uzyskały rangę dzieł instytucjonalnych, oraz o rozstrzygnięcia najwyższego szkockiego sądu o cywilnej jurysdykcji - Sądu Sesji ${ }^{19}$. Oprócz samej odpowiedzi na postawione pytanie warto

and Viscount of Stair: the Influence of Scholastic Moral Theology on Stair's Account of Restitution and Recompense, „Journal of Legal History” 29, 2008, s. 189.

15 Stair 2.1.17. „The several kinds and degrees of Possession being thus laid ope, it will be more easy to take up the common Notion and Nature of it, and it may be thus described. Possession is the holding or detaining of any thing by ourselves or others for our use. It is not every Holding of Detaining which makes Possession, for Depositors do detain, but because it is not for their use, they do not possess. So possession there must be an act of the Body, which is Detention and Holding, and an act of the Mind, which is the Inclination or Affection to make use of the thing detained, which being of the Mind, is not so easily perceivable, as that of us of the things".

16 John Erskine (1695-1768) - szkocki adwokat, profesor prawa szkockiego na uniwersytecie w Edynburgu, autor akademickiego podręcznika do nauki prawa szkockiego (Principles of the Law of Scotland in the Order of Sir George Mackenzie's Institutions of that Law, Edinburgh 1754) oraz dzieła instytucjonalnego The Institutes of the Law of Scotland, Edinburgh 1765.

17 Erskine 2.1.20. „Property would be but a name, without possession; for it is by possession alone that we are put in capacity to enjoy our property. Thus men of extensive property are said to have great possessions. But possession, when made use of in a strict sense, is defined, the detention of a subject, with an animus or design in the detainer of holding it as his own property. It is made up partly of fact, and partly of right. The fact consists in the detention of the subject which the possessor hath in his custody. The right consists in the view with which he holds it: He holds it in his own name, as his own property".

18 Nazwą tą określa się zarówno szkockie powództwo restytucyjne stosowane w razie pozbawienia posiadania w sposób bezprawny lub gwałtowny, jak i samo zachowanie sprawcy, które doprowadziło do takiego wyzucia z posiadania, dlatego też ów termin będzie wykorzystany dwojako — bądź to na określenie powództwa, bądź zachowania sprawcy czynu zabronionego.

19 Nieocenioną pomocą w przedstawieniu treści orzecznictwa w zakresie zlecenia i agencji był tzw. słownik Morrisona (W.M. Morrison, The Decision of the Court of Session, from its Institutions to the Present, in the Form of Dictionary, t. 1-21, Edinburgh 1801-1808.), stanowiący 
będzie przedstawić także same szczegóły konstrukcji prawnej powództwa, która tworzy hybrydę tradycyjnej formy ochrony posesoryjnej i oryginalnych szkockich rozwiązań.

Ochrona posesoryjna $\mathrm{w}$ prawie rzymskim opierała się na specyficznych uprawnieniach wyższych urzędników rzymskich, którzy mocą swojego imperium mogli przerywać spory o władztwo nad rzeczą, wydając stosowne zarządzenia określane jako interdykty ${ }^{20}$. Wśród interdyktów, zmierzających do restytucji posiadania odebranego w sposób bezprawny na pierwszy plan wysuwa się interdictum unde vi, skierowane przeciwko osobie, która odebrała rzecz siłą lub groźbą jej użycia.

Wydawać by się więc mogło, że to właśnie ten środek stanie się źródłem rozwiązań powództwa restytucyjnego, jeżeli jednak jest to źródło interesującego nas rozwiązania prawnego, to z pewnością nie jest ono jedyne ${ }^{21}$. Istotną wskazówkę znajdujemy w samej nazwie spuilzie, która wywodzi się od łacińskiego czasownika spolio, czyli „pozbawiać”, sam zaś charakter procesowy powództwa każe nam poszukiwać źródła szkockiej konstrukcji nie w administracyjnym środku znanym w prawie rzymskim, lecz istniejącym w systemie prawa kanonicznego powództwie restytucyjnym exceptio spolii, które umożliwiało restytucję posiadania rzeczy bez prowadzenia postępowania w przedmiocie prawa do rzeczy. Powództwo to początkowo umożliwiało odzyskanie posiadania przez złożonego z urzędu biskupa, ale z czasem rozszerzono jego zastosowanie na rzecz innych osób, a samo rozwiązanie wyszło poza ramy prawa kanonicznego, stając się uniwersalnym środkiem umożliwiającym odzyskanie utraconego posiadania ${ }^{22}$. Na prawo kanoniczne jako źródło inspiracji prawnej wskazuje często cytowana w orzecznictwie obu systemów prawnych zasada odnosząca się zarówno do exceptio spolii, jak i spuilzie ${ }^{23}$.

zbiór orzecznictwa Sądu Sesji, przedstawiony w układzie problemowym w dwudziestu jeden tomach. Słownik zawiera orzeczenia od roku 1532 (roku ustanowienia Sądu Sesji) do roku publikacji. Wszystkie orzeczenia dotyczące zagadnienia ubezpieczeń morskich znajdują się w dziewiątym tomie wspomnianego zbioru. Z uwagi na ciągłą numerację tomów, obejmującą ponad 20 tys. kart, oraz sposób cytowania orzeczeń w szkockim piśmiennictwie prawniczym w dalszej części opracowania publikator wyroków będzie podawany w formacie: Mor. 1234, cyfra oznacza kartę umieszczenia wyroku.

20 Więcej o naturze prawnej interdyktów oraz różnicy między interdyktem a powództwem W. Smith, A Dictionary of Greek and Roman Antiquities, London 1875, s. 642- 644, s.v. interdictum.

21 Bankton 2.1.31 wprost wskazuje, że skarga zastąpiła interdykty.

22 K.G.C. Reid, Property Law: Sources and Doctrine, [w:] A History of Private Law in Scotland, red. K.G.C. Reid, R. Zimmermann, Oxford 2000, s. 213.

23 „Spoliatus ante omnia est restituendus”. Decretum Gratiani, II.3.1.3-4. Cytowany fragment statuuje zasadę nakazującą dokonanie restytucji odebranego posiadania przed wdaniem się w spór w zakresie prawa do rzeczy. Kenneth Reid podaje szereg spraw, w których sąd, rozstrzygając powództwo z tytułu spuilzie, powołuje się na wspomnianą maksymę; K.G.C. Reid, Property Law..., s. 213, przypis 166 . 


\section{Definicja spuilzie}

Stair stwierdza, że spuilzie jest jednym ze zobowiązań naturalnych (natural obligations), czyli zobowiązań, mających źródło w zdarzeniu prawnym ${ }^{24}$. Pisarz instytucjonalny wskazał, że powództwo przysługuje osobie, której odebrano rzecz ruchomą bez zgody właściciela i podstawy prawnej ${ }^{25}$. Erskine zasadniczo posługuje się tożsamą definicją, jednakże w odróżnieniu od Staira wprost kładzie nacisk na fakt, iż wystarczyło odebranie samego posiadania rzeczy, bez względu na podstawę samego posiadania ${ }^{26}$. Także Bankton ${ }^{27}$ uznaje utratę posiadania, bez podstawy prawnej w przepisie lub w wyroku sądowym, jako podstawę wytoczenia powództwa z tytułu spuilzie (określając powództwo również jako spoilation). Dodatkowo autor ten zestawia ową definicję z definicją szkody, wskazując, że o ile zniszczenie rzeczy nie przynosi sprawcy korzyści, o tyle już zabór rzeczy tak ${ }^{28}$.

Pisarze instytucjonalni zauważali dualizm charakteru czynu, który prowadził do bezprawnego odebrania posiadania. Stair wskazuje, że restytucja rzeczy może nastąpić zarówno w wyniku postępowania karnego, jak i wytoczenia przed sądem cywilnym powództwa z tytułu spuilzie ${ }^{29}$, Bankton zaś utożsamia spuilzie z kradzieżą i rabunkiem ${ }^{30}$.

W wypadku zdarzeń kwalifikowanych jako kradzież i rabunek mamy do czynienia $\mathrm{z}$ brakiem podstawy prawnej, $\mathrm{w}$ drugiej zaś z tych grup dojdzie także do zaboru posiadania w związku z użyciem siły lub groźbą jej użycia. Dlatego też

24 Stair posługuje się w swoim dziele dychotomicznym podziałem na zobowiązania wynikające z czynności prawnych (conventional obligations) oraz na te, których źródłem są zdarzenia prawne (natural obligations), co sprawia pewną naturalną trudność terminologiczną wobec powszechnego rozumienia $\mathrm{w}$ tradycji cywilistycznej zobowiązania naturalnego jako niezaskarżalnego i nieegzekwowalnego obligatio naturalis (definicja zobowiązania naturalnego oraz dalsza literatura problemu jest dostępna w słowniku Bergera, Encyclopedic Dictionary of Roman Law, „Philadelphia" 1953, s. 604, s.v. obligatio naturalis).

25 Stair 1.9.16. „Spuilzie is the taking away of Moveables without consent of the owner or order of law".

${ }^{26}$ Erskine 3.7.16. „Spuilzie is the taking away or intermeddling with moveable goods in the possession of another, without either the consent of that other, or the order of law".

27 Andrew MacDouall, lord Bankton (1685-1760) — szkocki adwokat, wicedziekan szkockiej Rady Adwokackiej (Faculty of Advocates), u schyłku życia sędzia Sądu Sesji. Autor trzytomowego traktatu prawniczego wydanego między 1751 a 1753 rokiem An Institute of the Laws of Scotland, które przedstawia całość regulacji prawnej szkockiego systemu prawnego w komparatystycznym ujęciu z regulacjami angielskimi i poglądami przedstawicieli kontynentalnej jurysprudencji.

28 Bankton 1.9.124. „As Damage, in its proper sense, is Destroying or Diminishing one's Goods, without advantage to the offender, so Spuilzie is the violent Seizing or unlawful taking possession of goods from another, without his consent or order of law, for Lucre's fake".

29 Stair 1.9.16. „Thus things Stollen or Robbed, though they might criminally pursued, as Theft of Robbery, yet they may be civilly pursued as Spuilze".

30 Bankton 1.9.124. ,and comprehends both Theft and Robbery, which in a civil suit for damages, is termed a Spuilzie or Spoliation [...]". 
Bankton zauważa, że przed spuilzie można się — zgodnie z rzymską maksymą Vim vi repellere - bronić siłą, jak również siłą można dążyć do restytucji posiadania, gdy podjęto pościg za sprawcą ${ }^{31}$. Jednocześnie w sytuacjach mniej jednoznacznych posiadacz powinien dążyć do uzyskania restytucji w wyniku omawianego powództwa, ponieważ sam może narazić się na odpowiedzialność z tytułu spuilzie ${ }^{32}$.

\section{Legitymacja procesowa}

Problem legitymacji procesowej zarówno po stronie czynnej, jak i biernej jest istotny nie tylko z uwagi na odpowiedź na postawione na wstępie pytanie o zakres podmiotów uprawnionych do zgłoszenia roszczeń restytucyjnych implikujący przyjętą w systemie prawa szkockiego koncepcję posiadania, lecz także z uwagi na kształtowanie się zakresu ochrony posesoryjnej poprzez wyznaczenie kręgu potencjalnych podmiotów mogących odpowiadać na podstawie omawianego powództwa.

Pisarze instytucjonalni zgodnie stwierdzają, iż powództwo z tytułu spuilzie stanowiło środek procesowej ochrony posesoryjnej, a powód nie musi mieć innego tytułu do rzeczy niż samo posiadanie, z uwagi na domniemanie, jakie z niego wynika $^{33}$. Erskine podkreśla, że taka budowa skargi wynika z implementacji zasady, że nikt nie powinien być pozbawiany posiadania inaczej niż na podstawie wyroku sądu ${ }^{34}$, Bankton zaś, że posiadanie należy rozumieć w sposób szeroki,

31 Bankton 1.9.128. „but it is lawful not only by force to defend out possession of goods, endeavoured to be taken from us violently, Vim vi repeller, but likewise to recover the possession, by fresh pursuit of the invaders".

32 Bankton wskazuje tu na przypadek obrony siłą właściciela rzeczy zastawionej przed zabraniem jej w celu zaspokojenia długu innej osoby czy właściciela nieruchomości przed zabraniem rzeczy najemcy, na których dysponuje hipoteką. Nie rozstrzyga wprost tych kwestii, jednak jeżeli już doszło do utraty posiadania takich rzeczy, nie można dążyć do ich restytucji siłą bez groźby odpowiedzialności z tytułu spuilzie. Bankton 1.9.129. „The case varies where the authority of a judge intervenes, as in poinding; for tho the owner may forcible defend his goods from being carried off for another's debt; or the master of the ground, by his hypotec, stop poinding the tenant's goods till the year's rent is paid; yet if the poinding is compleated, he cannot at his own hand carry the goods, with our incurring spuilie, because a poinding is a sentence, and therefore he must have it removed by course of law, and not sibi ius dicere". Wskazana zasada stała się podstawą rozstrzygnięcia w sprawie Currie v. Crawford z 24 czerwca 1745 roku (Mor. 6206), w której Sąd Sesji uznał, iż właściciel gruntu, który odebrał siłą bydło najemcy stanowiące zabezpieczenie na poczet zapłaty czynszu, popełnił spuilzie i nie mógł korzystać z dobrodziejstwa zwrotu rzeczy w celu uchronienia się od penalnych skutków powództwa.

33 Stair 1.9.17. „In Spuilzie the Pursuer needs no other Title but Possession from whence in Moveable a Right is presumed [...]”.

34 Erskine 4.1.15. ,The pursuer, therefore, in action of spuilzie, need prove no more, than that he was in lawful possession of the subject libelled, which gives him a right to be ante amnia restored 
wskazując, że już samo posiadanie kluczy do pokoju legitymuje powództwo o zabór rzeczy, które się w nim znajdują ${ }^{35}$.

Legitymacja bierna była ukształtowana wyjątkowo szeroko, dotyczyła bowiem nie tylko samego sprawcy, lecz także wszystkich pomocników ${ }^{36}$, a ich odpowiedzialność miała charakter odpowiedzialności in solidum, albowiem jak podkreśla to Erskine, była to zasada stosowana przy wszystkich powództwach z czynów niedozwolonych ${ }^{37}$. Bankton oprócz pomocników wymienia także osoby, które zleciły zabór rzeczy, podkreślając odpowiedzialność każdego z nich za całość zobowiązania ${ }^{38}$.

Bankton zauważa, iż ogólna zasada odpowiedzialności pomocników będzie doznawała pewnych wyjątków. Autor przytacza przykład oszacowania rzeczy, która ma być przedmiotem bezprawnej egzekucji. W takiej sytuacji nie będzie odpowiadała ani osoba wybrana do oszacowania wartości przedmiotu, ani posłaniec, który przybył do niej ze stosownym zleceniem ${ }^{39}$. Bankton wskazuje, że ten brak odpowiedzialności wynika $\mathrm{z}$ faktu, iż działali oni w dobrej wierze, w celu wykonania orzeczenia sądowego, a to osoba, która posłużyła się bezpodstawnym lub sfałszowanym rozstrzygnięciem, powinna ponieść odpowiedzialność ${ }^{40}$. Jednocześnie zaznacza, że jeżeli spuilzie jest wynikiem nieprawidłowego działania posłańca, który postępował bezprawnie, to on, a nie jego mocodawca, będzie od-

to the possession, for the action is grounded on this plain principle, That no man is to be stripped of his possession, but by the order of law".

35 Bankton 1.9.126. „The pursuers title, in an action of spuilie, is Possession of the goods, and which is sufficient by having the keys to the room, where they lay". Bankton podaje w dalszym zakresie przykład sprawy Maxwel v. Maxwel rozstrzygniętej wyrokiem Sesji z dnia 27 lipca 1676 roku, (Mor. 14729) jednocześnie zauważając, że inny wyrok zapadłby, gdyby owych zniszczeń dokonał właściciel domu, w którym znajdują się zamknięte drzwi.

36 Jednocześnie musiano wprost dowieść działania w porozumieniu. Przykładem odmiennej sytuacji jest niepociągnięcie do odpowiedzialności męża, którego żona dopuściła się spuilzie bez jego wiedzy. Próba dochodzenia jego odpowiedzialności spotkała się z oddaleniem powództwa w sprawie Scot v. Banks z 2 lutego 1628 roku (Mor. 6015).

37 Erskine 4.1.15. ,Spuilzie is not only competent against spoliator, or principal defender, but against all abettors, each of whom is liable in solidum, without recourse against the rest, which is indeed the rule in all actions arising ex delicto".

38 Bankton 1.9.130. „The action of spuilie is good against all parties concerned, whether Principals or Accessaries, and against every one of the for the whole damage and profits, tho payment by one liberates the rest".

39 Bankton 1.9.131. „But tho accesaries to the fact are regular liable, yet they are sometimes freed from spuliei, for instance apprissers, who are called by a messenger to appreciate goods in order to a poinding, which thereafter is found a spuili, are innocent, tho the poinder be guilty and the messengers themselves will be excused in poindings, when the party concerned shall be made liable in a spuilie".

40 Bankton 1.9.131. „The reason is, that all those are employed in their office which they, bona fide, execute upon the faith of the letters, that is, a judicial warrant and therefore the procurer of the letters wrongfully must answer for the consequences". 
powiedzialny ${ }^{41}$ — taka sama zasada miała zastosowanie w przypadku urzędnika, który w sposób nieprawidłowy przeprowadził egzekucję wyroku sądowego ${ }^{42}$.

Liczba zdarzeń, które można kwalifikować jako spuilzie, wynika bez wątpienia z pewnego poziomu cywilizacyjnego ${ }^{43}$, który będzie wpływał na mnogość sytuacji kradzieży i rabunków, jednak w tekstach źródłowych, ze względu na konstrukcję prawną powództwa, zwraca się uwagę na dwa szczególne przypadki: dokonanie spuilzie przez właściciela rzeczy oraz przez jej nabywcę.

Erskine słusznie zauważa, że spuilzie mogło być popełnione nie tylko przez osoby obce, lecz także przez samego właściciela względem rzeczy będących jego własnością. Pisarz uzasadnia to faktem, iż prawo własności nie może prowadzić do sytuacji, w której właściciel będzie sędzią we własnej sprawie lub będzie doprowadzał do wyzucia z posiadania osoby, która posiadanie nabyła zgodnie z prawem ${ }^{44}$. Bankton wskazuje, że przedmiotem postępowania był jedynie fakt bezprawnego odebrania posiadania, nie zaś prawo do rzeczy. Autor podkreśla, że powództwo restytucyjne zmierzało do przywrócenia stanu sprzed odebrania posiadania przemocą, a ewentualne spory o tytuł prawny nad rzeczą mogły toczyć się dopiero po dokonaniu owej restytucji ${ }^{45}$. Jednocześnie sam właściciel często

41 Bankton 1.9.131. „but if the spuili is inferred from messenger's not observing the legal solemnities the employer is free, and the messenger only subjected".

42 Tak chociażby w sprawie Lord Justice Clerk v. Home of Linthel, w której wyrokiem z dnia 28 lutego 1668 roku (Mor. 13985) Sąd Sesji uznał brak odpowiedzialności sędziego za działania urzędnika, który wykonując wyrok, dokonał zaboru wołu, będącego jako zwierzę gospodarskie stanowił przedmiotem zwolnionym z egzekucji.

${ }^{43}$ Bankton wspomina o pewnym rodzaju żebraków, którzy podróżowali grupami i trudnili się kradzieżą, w szczególności jedzenia. Karano ich na równi ze złodziejami i rabusiami, w tym możliwością zabicia ich na miejscu, jeżeli stawiali opór przed zatrzymaniem lub uciekali. W zakresie wyrządzonych szkód odpowiadali oni na podstawie spuilzie, lecz jak wskazuje autor instytucjonalny ich ubóstwo czyniło próbę egzekucji wyroku zasądzającego bezskuteczną. Bankton 1.9.125. „There was of old a kind of spuiliers, very frequent and troublesome in this country, called Katharines or Soners: they were masterful sturdy beggars, that went in companies, oppressing the people by consuming victuals, and taking away goods without consent of the owners and some such are at this day. There are several statues for repressing and punishing them as Thieves and Rievers, i.e. Robbers, and if they will not suffer themselves to be seized, they may be killed, by those in pursuit, with impunity; no doubt, they are liable on an action of spuilie, to the party injured, but which, for the most part, must be fruitless thro their poverty".

44 Erskine 4.1.15. „Spuilzie may, by the definition there given of it, be committed, not only by strangers, but even by the owner of the moveable goods carried off because a right of property itself cannot justify the proprietor in assuming power of judging in his own cause, or of turning one out of possession who had acquired it lawfully".

45 Bankton 1.9.126. „And if the possession was peaceable, even the true owner, seizing the goods from possessor, will be liable to spuilie, nor will his pretence of property be regarded in this suit, according to the maxim, that spoliatus ante omnia est retituendus. The party that is violent deprived of the possession must be first restored, and then question of property considered". 
był ofiarą spuilzie - działo się to nie tylko w wyniku zaboru dóbr, lecz także poprzez uniemożliwienie właścicielowi wejścia w posiadanie własnej rzeczy ${ }^{46}$.

Spuilzie stanowiło wrodzoną wadę prawną (labes realis ${ }^{47}$ ), co sprawiało, iż skarga była skuteczna także względem osób trzecich, które w dobrej wierze nabyły przedmioty uzyskane $\mathrm{w}$ ten sposób przez sprzedawcę ${ }^{48}$. Nabywca ponosił odpowiedzialność nie tylko przez utratę przedmiotów pochodzących ze spuilzie, lecz także przez brak prawa do dochodzenia zwrotu zapłaconej ceny ${ }^{49}$. Co więcej, w przypadku znalezienia w posiadaniu osoby takich przedmiotów nabywca mógł odpowiadać za całość utraconych w konkretnej sytuacji rzeczy, chyba że udowodnił, iż nabył jedynie ten przedmiot i to w sposób prawidłowy ${ }^{50}$.

\section{Specyfika postępowania w sprawie o spuilzie}

Z uwagi na gwałtowny i bezprawny charakter zdarzenia, które prowadziło do utraty posiadania, prawo szkockie przyznawało w przypadku spuilzie dwa szczególne uprawnienia stronie powodowej: możliwość ustalenia wysokości odszkodowania w drodze środka dowodowego, jakim była przysięga powoda (oath

46 Bankton 1.9.124. ,it for most part occurs by seizing the goods, but it will be likewise inferred by excluding the owner from the possession of them".

47 Tym terminem określano wrodzoną wadę tytułu prawnego do rzeczy, która prowadzi do umożliwienia restytucji rzeczy lub prawa także przeciwko nabywcy, który jest posiadaczem w dobrej wierze. Tę cechę miały rzeczy skradzione, odebrane w wyniku spuilzie czy nabyte na podstawie podrobionego dokumentu, jednak oszustwo nie miało już tak dalekosiężnych skutków i nabywca rzeczy, która przez sprzedawcę była uzyskana w ten sposób, mógł utrzymać się we władztwie nad rzeczą. Zob. szerzej W. Bell, A Dictionary and Digest of the Law of Scotland, Edinburgh 1838, s. 572, s.v. labes realis.

48 Stair 1.9.16. „Spuilzie inurit labem realem, whereby the Goods may be recovered from Purchasers bona fide".

49 Bankton 1.9.130. „it is competent against lawful purchasers from spuiliers, for restitution, without refunding the price”. Bankton przywołuje tutaj sprawę Hay v. Leonard rozstrzygniętą wyrokiem Sądu Sesji z 21 listopada 1677 roku (Mor. 10286), w której powód domagał się zwrotu skradzionej perły od jej nabywcy. Sędziowie oddalili pozew, uznając, iż osoba, która dopuściła się spuilzie, była partnerem powoda w przedsięwzięciu poszukiwania pereł i zakup od jednego z partnerów jest wystarczający do uznania podstawy prawnej posiadania pozwanego, jednocześnie wskazując, że jeśli by nie istniało porozumienie między powodem a sprawcą spuilzie, nakazaliby restytucję perły.

50 Bankton 1.9.130. „for truly spuilie is theft and therefore inert label realm; as also does robbery, which is theft aggravated by violence, and term Spuilie seems rather to import this last: part of spulied goods, found in one's possession de recenti, subject him to the whole goods libelled, unless he instruct that he got them in a fair way". Bankton odwołuje się do sprawy Gordon \& Robertson v. Menzies rozstrzygniętej wyrokiem Sądu Sesji z 11 czerwca 1680 roku (Mor. 1680), w której w stajni najemcy odkryto jednego z pięciu zrabowanych koni. Sąd Sesji uznał, że to po stronie pozwanego spoczywa ciężar udowodnienia, iż wszedł $\mathrm{w}$ posiadanie konia zgodnie z prawem, pod rygorem uznania, że to on odpowiada za spuilzie i to być może w pełnej wysokości utraconych dóbr. 
in litem ${ }^{51}$ ), która uwzględniała również wartość sentymentalną rzeczy (pretium affectionis $)^{52}$, oraz możliwość zasądzenia specjalnego odszkodowania, będącego konsekwencją utraty nadzwyczajnych pożytków (violent damages).

Ciężar dowodu nakładany na powoda, nakazujący mu określenie i udowodnienie, jakie przedmioty zostały mu odebrane $\mathrm{w}$ wyniku spuilzie, był łagodzony poprzez umożliwienie mu złożenia przysięgi przed sądem co do zakresu i wartości odebranych rzeczy, natomiast powód wciąż musiał udowodnić, że doszło do ich odebrania w sposób bezprawny ${ }^{53}$, który jednocześnie był niedopuszczany, gdy istniał dowód (na przykład z zeznań świadka) co do liczby odebranych rzeczy ${ }^{54}$. W zakresie samej możliwości przeprowadzenia przysięgi jako środka dowodowego Erskine wskazuje, że co do zasady leżał on w wyłącznej jurysdykcji Sądu Sesji (nobile officium), na mocy ustawy z 1503 roku, jednak część przypadków spuilzie poddano pod jurysdykcję sądu szeryfa, co doprowadziło do możliwości składania takich przysiąg również przed niższymi sądami, a sami szeryfowie uzyskali możliwość modyfikowania ilości i wartości odebranych rzeczy, które zwyczajowo określano właśnie w drodze przysięgi ${ }^{55}$.

Przechodząc do zakresu zasądzenia, należy wskazać, że spuilzie jako szczególna forma postępowania restytucyjnego obejmowała nie tylko sam zwrot rzeczy, lecz także wszystkie korzyści, które mógłby odnieść jej posiadacz ${ }^{56}$. W razie niemożności uzyskania zwrotu zabranego przedmiotu $\mathrm{w}$ naturze zobowiązanie

51 Jest to jeden z dwóch przypadków w prawie szkockim, które umożliwiały przeprowadzenie postępowania dowodowego w zakresie wysokości wyrządzonej szkody na podstawie przysięgi poszkodowanego. Drugim z przypadków była odpowiedzialność na zasadach custodia, która obciążała podmioty prowadzące działalność taką jak prowadzenie gospody lub stajni. Zob. szerzej W. Bell, A Dictionary and Digest of the Law of Scotland, Edinburgh 1838, s. 379, s.v. evidence.

52 Bankton 1.9.133. „The special incidents in an action of spuilsie are pursuer's Oath. By the first he is entitled to the value of the thing, according to his price of affection, what he swears it was worth to him, in case it is not restored in a good condition as when taken away".

53 Stair 1.9.18. „In Spuilzie, the Fact being proven or acknowledged as to some particulars Libelled, the Pursuers Oath will be admitted to prove the rest of the Libel, though consisting of divers kinds of things". Stair jako przykład takiego rozwiązania wskazuje na sprawę Brown v. Murray, która została rozstrzygnięta wyrokiem Sądu Sesji z 8 marca 1628 roku (Mor. 9361).

54 Bankton 1.9.133. „of there is a concurring proof as to the quantity of the goods spilled, no oath in litem is allowed thereon, but only in respect to the values and violent profits". Pośrednie rozwiązanie zostało wykorzystane w cytowanej przez Banktona sprawie Fea v. Elphiston rozstrzygniętej wyrokiem Sądu Sesji z 2 stycznia 1697 roku (Mor. 9367), w której Sąd dopuścił możliwość złożenia przysięgi w przypadku sprzecznych zeznań świadków.

55 Erskine 4.1.15. „The administering of oaths in litem, is, in the general case, peculiar to the court of session, as being act nobilis offici; yet as, by special statute, 1503, c. 65 , recent spuilzie are left open to the cognisance of sheriffs, sheriffs may not only put an oath in litem to the pursuer, but modify the extent or quantity of the goods sworn to by him".

56 Stair 1.9.16. „obliging to Retribution of the things taken away, with all possible Profits, or Reparation thereof according to Aestimation of Injured, made by his iusiurandum in litem [...]". 
przekształcało się w odpowiedzialność odszkodowawczą sprawcy ${ }^{57}$, która obejmowała również wartość emocjonalną przedmiotu dla powoda.

Jeżeli odszkodowanie określone przez powoda jest zbyt wygórowane, sędzia ma prawo do jego miarkowania. Sędzia może również ograniczyć liczbę dóbr, których restytucji na podstawie przysięgi dochodzi powód, a po dokonaniu przysięgi może modyfikować ${ }^{58}$ podane przez powoda wartości. Bankton wskazuje, że dzieje się tak, ponieważ to w mocy sędziego jest stosowanie uprawnienia w postaci przysięgi, jak również odmowa jego zastosowania ${ }^{59}$.

Obowiązek zwrotu pożytków z rzeczy także został rozszerzony poprzez nakazanie zwrotu pożytków określanych jako violent profits. Pod tym terminem rozumie się korzyści, które wynikają z posiadania i wykorzystania rzeczy w sposób jak najbardziej intensywny. Nie stanowią one zwykłych pożytków, które posiadacz uzyskałby w wyniku korzystania z rzeczy ${ }^{60}$, żądać zaś ich można jedynie w odniesieniu do rzeczy, z których można uzyskiwać częste, nawet codzienne korzyści ${ }^{61}$. Na mocy tego rozwiązania można było domagać się odszkodowania stanowiącego równowartość produktów, które zostałyby wytworzone za pomocą zabranych narzędzi czy wartości potomstwa zwierząt, które odebrano ${ }^{62}$. Wysokość odszkodowania będzie zależeć od okoliczności zaboru rzeczy oraz oceny sędziego ${ }^{63}$, samo zaś odszkodowanie mogło stanowić przedmiot opodatkowania. Jednocześnie jednak sąd, dokonując oceny zasadności zasądzenia takiego odszkodowania, ograniczał się do sytuacji, gdy utracone korzyści powstawałyby w sposób typowy i bezpośredni ${ }^{64}$.

57 Erskine 3.7.16. „When spuilzie is committed, action lies against the delinquent, not only for restoring to the former possessor the goods or their value, bout for all the profits he might have mede of these goods, had it not been for the spuilzie".

58 Takie rozwiązanie zastosowane w sprawie Jardine v. Lady Melgum rozstrzygniętej wyrokiem Sądu Sesji z 20 marca 1573 roku (Mor. 9359), w której początkowo postępowanie prowadzono, opierając się na dowodzie ze świadków i na tej podstawie stwierdzono fakt zaboru części zboża, po czym dopiero dopuszczono powoda do złożenia przysięgi w zakresie całości utraconych plonów.

59 Bankton 1.9.133. ,which however, if exorbitant, may be taxed by the judge, the judge may either tax the quantity within which the party is to swear or after he has sworn, modify and restrict it, because it is in his power to allow the benefit of the oat in litem, or not, as he sees cause [...]".

60 Erskine 3.7.16. „These profits are esteemed by the pursuer's own oath and get the name of violent, because they are due in no other case than of violence or wrong".

61 Bankton 1.9.133. ,Violent profits are so termed, because they are beyond the ordinary profits the pursuer used to make of goods, and are such as might have been made of them by the utmost industry: horses, oxen, cows and labouring instruments; afford daily profits, but corns and such like afford none".

62 Bankton 1.9.133. ,it includes likewise the product of young of cattle [...]”.

63 Stair 1.9.16. „The profit of things Spuilzied, are called violent profits, because they are not such ordinary profits as the Person spuilzied used to make of the Goods, but such as he might have made thereof, as where the things Spuilzied have profits, as Horse, Oxen or other Cattle, and Instrument or other Tools, but Corns and the like have no profits. But the modification depends much upon the violence and atrocity of the Spuilzie and the Arbitriment of the Judge".

${ }^{64}$ Bankton 1.9.133. ,these violent profits are at the modification of the court, it extends farther to other damages sustained by the pursuer, besides the loss of the fruits or profits of the thing spulied 
Specyficznie rozstrzygnięto możliwość dokonywania potrącenia w sprawie wytoczonej z tytułu spuilzie. Wyjątkowo dopuszczano je, gdy powód dokonał na szkodę pozwanego spuilzie w wysokości co najmniej tożsamej z dochodzonym roszczeniem lub gdy powodem była osoba o wątpliwej reputacji ${ }^{65}$. Jednocześnie autor wskazuje, że kompensacja nie umożliwiała uchylenia się od spuilzie, ponieważ prowadziłaby do sytuacji, iż osoba jest sędzią we własnej sprawie i choć w niektórych mniej cywilizowanych częściach kraju takie rozwiązanie jest stosowane, powinien być to raczej wyjątek, gdy istnieją trudności przy stosowaniu prawa, nie zaś zasada ${ }^{66}$.

Wyjątkowo odebranie rzeczy możliwe było jeszcze w trakcie postępowania, jeżeli odnaleziono je podczas przeszukania. Miało to miejsce na podstawie stosownego zarządzenia sędziego lub sędziego pokoju, które jednak nie było wydawane, gdy rzeczy posiadała osoba, która nabyła je zgodnie z prawem ${ }^{67}$. W przypadku dokonania kradzieży lub rabunku poszkodowany mógł zwrócić się o pomoc do takich urzędników, jak szeryf czy sędzia pokoju, a ci pod groźbą odpowiedzialności odszkodowawczej byli zobowiązani do zgromadzenia grupy, która miała odzyskać rzeczy i zatrzymać sprawców, rzeczy zaś powinny być zwrócone właścicielowi ${ }^{68}$. Jeżeli jednak niemożliwe było odzyskanie rzeczy, które zostały zniszczone lub utracone, odpowiadali za nie członkowie rady parafialnej (heritors

but this comprehend only immediate damage or loss of gain, and not consequential or extrinsic damages, and the offender is also liable in full expenses of the fruit, and interest of value of the subject, when it affords no violent profits". Dobrą ilustracją opisanego problemu jest sprawa Ker v. Dunbar rozstrzygnięta wyrokiem Sądu Sesji z 5 lutego 1706 roku (Mor. 16460), w której właściciel destylarni dochodził zwrotu zabranego na mocy wadliwej podstawy prawnej kociołka oraz aparatury destylacyjnej. Właściciel destylarni dążył również do uzyskania zwrotu utraconych korzyści oraz poniesionych strat w postaci: kosztów najmu lokalu, zmarnowanych materiałów gorzelniczych i słodu oraz utraconego zysku. Sąd Sesji nie przyznał mu owych dodatkowych odszkodowań, ponieważ stwierdził, że mógł te zyski odnieść, a przed stratami się uchronić, jeżeli wstawiłby do destylarni inny kociołek i podjął prowadzoną działalność.

65 Bankton 1.9.144. „Spulie is, in the last place, elide by compensation, upon the pursuer's having spuilied as much of the defenders's goods, in cause the pursuer was a broken man, and a notorious thief of a clan than could not be reached by due course of law".

66 Bankton 1.9.144. „but in common cases, compensation will not be excuse, because at that rate, every man would be judge in his own cause. Absolute necessity made way for the foresaid privilege, and therefore it may be a doubt that the Highlands are more civilised, if it is allowable at this day, but truly, in divers places of the Highlands and Isles, the law has not its due course, so that, in these circumstances, the expedient is still necessary, that compensation of injuries ought to be allowed".

67 Bankton 1.9.127. „Stolen good may be summarily recovered on a search, by warrant of the judge ordinary or a justice of the peace, unless they are possessed by a lawful purchaser".

68 Bankton 1.9.127. „It is likewise provided, that in case of theft, robberies or depredations, the owner of the goods may immediately complain to sheriff, or any of the justices of peace or constables of the parish where it was committed, for redress, and they must forthwith, on pain of being liable for the value of goods, call together sensible men of the parish to concur in the recovery of the goods and apprehension of the offenders, who must obey under the pain foresaid". 
of parish), ponieważ w tej sytuacji uznawano winę osób, którym nie udało się doprowadzić do odzyskania rzeczy, tak jakby udzieliły pomocy w dokonaniu kradzieży ${ }^{69}$. Wskazana tu procedura ma jednak charakter wyjątkowy, w przypadku kradzieży wielu rzeczy dokonanej w grupie i z użyciem siły — w pozostałych sytuacjach należy szukać restytucji w drodze normalnego postępowania sądowego z tytułu spuilzie wytoczonego przed Sądem Sesji lub jednym z niższych sądów ${ }^{70}$.

\section{Charakter powództwa}

Jednym z problemów zauważanych przez pisarzy instytucjonalnych jest zagadnienie kwalifikacji prawnej powództwa z tytułu spuilzie. Zasadniczo w sposób zgodny uznawali oni, że powództwo ma charakter karny w zakresie, w jakim wysokość odszkodowania jest kształtowana przez przysięgę powoda oraz violent profits, i z tego powodu co do zasady nie przysługuje względem dziedziców sprawcy $^{71}$, którzy zobowiązani są jedynie do dokonania restytucji ${ }^{72}$. Jednocześnie jeżeli do dziedziczenia doszło już po wniesieniu powództwa, to dziedzic lub kurator spadku odpowiadają z tytułu spuilzie ${ }^{73}$.

69 Bankton 1.9.127. „If the goods are thus recovered, they must be delivered to the owners and offenders, if apprehended, must be secured to undergo trail; but if the owner after his utmost endeavours, cannot, with the concurrence foresaid, recover goods, the heritors of the parish, where goods where disposed, of, are declared liable to the owner in the value, Hence it is plan, that those who fail to concur in the recovery of the goods, and the heritors of the parish, where they are disposed of, are adjudged accessaries to the theft or depredation, for otherwise they could not be subjected to the value of goods".

${ }^{70}$ Bankton 1.9.128. „But this summary procedure can only take place when theft or robbery is committed by persons assembled together, and to a great extent, by force, as is the import of the term (Depredation) used in the statue, and while the matter is recent, as appears from the strain of act, for otherwise the recovery of goods stolen, robbed or spuilzied, must be by ordinary course of law, and is most regular by an action of spuilzie before the Court of Session of inferior courts of justice".

71 Natomiast w zakresie dziedziczności uprawnienia do wniesienia powództwa nie było żadnych problemów - Stair, 1.9.17., wskazuje tutaj na sprawę Russel v. Kerse z 26 lipca 1626 roku (Mor. 14733), w której uznano legitymację czynną wdowy do wniesienia powództwa o restytucję skradzionego jej mężowi zboża.

72 Bankton 1.9.132. „This action is partly Penal, so dar as it concerns the prices of affection by an Oath in litem and the Violent Profits and therefore it is regularly not competent, as such, against the heir and only Simple Restitution, and true value can be demanded in that case [...]".

73 Bankton 1.9.132. „but if litiscontestation was made with the offender, then all of peculiarities of spuilie will take place against his heir or executor, as if the question were with himself". Erskine 4.1.15. „Actions of spuilzie, ejection and intrusion are penal where they include the violent profits". W sprawie Lewars v. Carmichael rozstrzygniętej wyrokiem Sądu Sesji z dnia 5 czerwca 1711 roku (Mor. 10348) nie dopuszczono do złożenia przez powoda przysięgi w zakresie wartości i rodzaju dóbr utraconych w wyniku spuilzie z uwagi, że sprawca zmarł przed wezwaniem go do uczestniczenia w sprawie, postępowanie zaś w całości toczyło się przeciwko jego spadkobiercy. Co 
W przypadku wielości sprawców, z uwagi na oparcie odpowiedzialności deliktowej na konstrukcji odpowiedzialności in solidum ${ }^{74}$, zapłata przez jednego ze sprawców prowadziła do uwolnienia wszystkich pozostałych ${ }^{75}$.

$\mathrm{W}$ odniesieniu do terminu wytoczenia powództwa należało tego dokonać w okresie trzech lat od zdarzenia. Jednocześnie upływ tego okresu nie niweczył całkowicie możliwości restytucji odebranych rzeczy, pozbawiał jednak powoda uprzywilejowanej pozycji procesowej przejawiającej się w możliwości uzyskania wyższego odszkodowania oraz ułatwień w postępowaniu dowodowym w postaci oszacowania wysokości szkody na podstawie przysięgi złożonej w trakcie toczącego się postępowania ${ }^{76}$. Jeżeli $\mathrm{w}$ tej sytuacji występowało więcej podmiotów zobowiązanych do restytucji, to po upływie trzyletniego okresu od wniesienia powództwa nie odpowiadali już oni in solidum, ale jedynie w sposób równy, chyba że część dłużników zawiniła bardziej ${ }^{77}$. Stanowisko to potwierdza Erskine ${ }^{78}$, dodając do tego, że zwykła restytucja jest możliwa w ciągu czterdziestu lat od zdarzenia $^{79}$.

więcej mimo udowodnienia faktu popełnienia spuilzie przez spadkodawcę odpowiedzialność spadkobiercy została ograniczona do zwykłej restytucji.

74 J. Chisholm, Green's Encyclopaedia of the law of Scotland, t. 11, Edinburgh 1899, s. 390392, s.v. spuilzie.

75 Tak chociażby w sprawie rozstrzygniętej przez Sąd Sesji z 17 czerwca 1613 roku — Douglas v. Young (Mor. 14736).

76 Stair 1.9.24. „There is also common Exception against Spuilzies upon Prescription of three years, they not being pursued within that space, after the committing thereof, and that by express Statue. But this prescription is only against the Spuilzie as such, so that it taketh away the Privilege thereof, as to violent profities \& iusiurandum in litem, yet it may thereafter be pursued as wnrongous Intromission, for restitution only".

77 Stair 1.9.24. ,and if many be pursued, they are not lyable in solidum, but equally, unless a greater Intromission of some of them be proven". Zasada, o której wspomina tutaj pisarz instytucjonalny, pokrywa się z tezą orzeczenia Sądu Sesji ze stycznia 1687 roku w sprawie Strachan v. Morison (Mor. 14710).

78 Erskine 3.7.16. „The words of the statue limiting the duration of actions of spuilzie to three years after the commission of the fact on which the action is grounded, would if understood in full extent, cut off all right of action competent to the person despoiled against the delinquent after that period. But there words is only meant the action of spuilzie, as it includes the privileges of the violent profits and of proving the extent of the pursuer's damage by his own oath; a species of evidence rejected by the common rule of law".

79 Erskine 3.7.16. „Action for the simple restitution of the goods, and ordinary damages, therefore is competent against despoiler at any time within forty years". Autor jako przykład rozstrzygnięcia po upływie okresu trzyletniego podaje wyrok Sądu Sesji z 16 marca 1627 roku w sprawie Hay v. Ker, w którym na rzecz powoda zasądzono jedynie zwykłe pożytki (Mor. 11069). 


\section{Formy obrony przed spuilzie}

Uprawnienia przyznawane powodowi w postępowaniu restytucyjnym istotnie polepszały jego sytuację, dlatego — wobec niezbyt surowo zakreślonej podstawy powództwa w postaci bezprawności działania — konieczne było określenie sytuacji, w których mimo wszystko nie dochodziło do spuilzie. Pisarze instytucjonalni wyróżniali zatem wiele form obrony przed omawianym powództwem. Formy te możemy podzielić na bezwzględnie skuteczne i względnie skuteczne. Pierwsza kategoria stanowiska pozwanego prowadziła do oddalenia powództwa, druga uchylała jedynie penalny charakter środka procesowego, pozwany zaś wciąż zobowiązany był do restytucji odebranego posiadania ${ }^{80}$.

Do pierwszej kategorii form obrony zaliczano udowodnienie, iż do nabycia lub przejęcia dóbr doszło zgodnie z prawem (na podstawie odpowiedniego przepisu lub wyroku sądowego) ${ }^{81}$, jak również udowodnienie, że dobra zostały dobrowolnie dostarczone przez poprzedniego posiadacza ${ }^{82}$. Te obrony stanowiły zaprzeczenie twierdzeń powoda i w razie ich skutecznego podniesienia skutkowały zakończeniem postępowania w sposób korzystny dla pozwanego.

Z kolei katalog sytuacji, które pozbawiały spuilzie jedynie jej penalnego charakteru, ograniczając żądanie do zwykłego zwrotu, był znacznie szerszy.

Bankton w pierwszej kolejności wymienia tu działanie opierające się na wadliwej podstawie prawnej ${ }^{83}$. Stanowisko to potwierdza Erskine, który odwołuje się do zasady, iż jakikolwiek tytuł do rzeczy niweczył przesłankę bezprawności, a zatem uniemożliwiał zasądzenie z tytułu spuilzie - quilibet titulus excusat a spolio $^{84}$. Wadliwość podstawy mogła wynikać z działania na podstawie zwyczaju niemającego mocy prawnej ${ }^{85}$, gdy pozwany działał względem wierzycieli

${ }^{80}$ Erskine 4.1.15. „But these defences afford no protection to the defender, except as to the penal consequences of the action; they are utterly ineffectual in so far as concerns simple restitution and damages".

81 Stair 1.9.19. „Spuilzie is eleided First, If the Deed was warrantably done, at least bona fide, by a colourable Title, as by Custom".

82 Stair 1.9.20. „The second Exception against Spuilzies, is voluntar delivery, which was sustained, though it seemed contrair to the Libel".

${ }^{83}$ Bankton 1.9.134. „A colorauble title to possess, which gives probable ground to intromission, will elide spuili, as to the peculiarities, tho restitution of the real value is still due, even a general disposition was found sufficient, no violence being used in attaining real possession".

${ }^{84}$ Erskine 4.1.15. Jako przykłady rozstrzygnięć opartych na tej zasadzie podaje sprawę Berfoord v. Kingstoun z 27 stycznia 1665 roku (Mor. 1817) dotyczącą zaboru zboża z ziemi o spornym statusie prawnym oraz sprawę Thin v. Langshaw z listopada 1683 roku (Mor. 14753), w której nakazano pozwanemu zwrot konia, zatrzymanego na podstawie uchylonej ustawy.

${ }^{85}$ Tak rozstrzygnął Sąd Sesji w sprawie M'Kay v. Menzies zakończonej wyrokiem z 14 marca 1635 roku. Udało się w nim uniknąć zasądzenia pozwanego z tytułu spuilzie, w sytuacji, w której pozwany zatrzymał konia powoda powracającego z młyna ze zmielonym ziarnem, powołując się 
powoda w oparciu o jego dawną dyspozycję $e^{86}$ lub gdy doszło do odebrania rzeczy na podstawie nieważnego dokumentu ${ }^{87}$.

Jeżeli doszło do popełnienia spuilzie, sprawca mógł uchylić się od odpowiedzialności, jeżeli zwrócił rzecz w stanie nienaruszonym w ciągu dwudziestu czterech godzin od dokonania zaboru rzeczy, a jeśli nastąpiłoby to później, to gdy zwrot rzeczy został zaakceptowany przez powoda, a on sam zatrzymałby rzeczy $^{88}$. W przypadku wątpliwości, czy doszło do prawidłowego zaoferowania zwrotu rzeczy zabranych w wyniku spuilzie, a zatem konieczności ich przyjęcia, rozstrzygał sędzia ${ }^{89}$. Upływ opisanego trzyletniego terminu od zgłoszenia skargi również był jedną z form względnie skutecznej obrony procesowej ${ }^{90}$.

Prawo do ochrony swojej własności też prowadziło do dość specyficznego wyjątku od spuilzie - można było bowiem bez podstawy prawnej zatrzymać rzecz bądź zwierzę, które niszczyło grunt drugiej osoby. Można było wtedy takie zwierzę zamknąć, zapewniwszy wodę i jedzenie, i trzymać aż do zapłaty za wyrządzone szkody. Jednocześnie jednak, jeśli doszłoby do korzystania z takiej rzeczy przed rozstrzygnięciem sądowym, to dochodziło do popełnienia omawianego czynu zabronionego ${ }^{91}$.

przy tym na miejscowy zwyczaj. Choć sędziowie Sądu Sesji stwierdzili, że takie postępowanie było nieprawidłowe, uznali, że nie istnieją podstawy do spuilzie, a jedynie zwykłej restytucji.

${ }^{86}$ Sprawa Kirkwood v. Ferguson z 19 lipca 1633 roku (Mor. 2117) oraz sprawa Irving v. M'Kartney z 30 stycznia 1662 roku (Mor. 14750).

87 Sprawa Bailie v. Lord Torpichen z 10 stycznia 1611 roku (Mor. 14747). Ta sama sytuacja miała miejsce przy stwierdzeniu braku odpowiedzialności posłańca, który zajął dobra, opierając się na wadliwym nakazie sądowym wydanym na podstawie nieprawdziwego stanu faktycznego sprawa Scot v. Burlie z 20 lutego 1528 roku (Mor. 14758).

88 Stair 1.9.23. „The fifth Exception against Spuilzie, is restitution of the Goods Spuilzied within twenty four hours, re integra, and is also eleided by Restitution of the Goods, if they be accepted and keeper by the Pursuer. Erskine 4.1.15 This action, when it is pursued recently and includes the violent profits, being penal, is elided by the defender's having a probable ground of excuse or by his voluntary restitution de recenti of the good illegally carried off, cum amnia causa".

89 Bankton 1.9.140. „Spuilie will likewise be elided, by restitution of the thing in the same condition, within a short time; and it depends upon the arbitrament of the judge, whether restitution was duly offered, and ought to have been accepted. Twenty four hours is generally thought to be reasonable time".

90 Bankton 1.9.141. „Prescription of three years, after the fact committed, does also extinguish the action of spuilie as to its privileges, but still it may proceed for simple restitution or the ordinary value, and then each of the defenders is only liable equally, unless a greater share is proved upon any of them, the action being then but res persecuratoria".

91 Bankton 1.9.143. „It is privilege allowed to the possessors of ground, that if they fond other mens goods and cattle destroying their own corn or grass, they may secure them in a safe place or pound, without hazard of spuilzie, giving them water and fodder, or intimating to the owner to do it; but if they make use of such goods, before they get the damage lawfully noticed and taxed by the sentence of judge, and the goods lawfully pounded for the same, they will be liable in a spuilie". Ową zasadę obrazuje rozstrzygnięcie w sprawie Duncan v. Kids z dnia 10 lutego 1676 roku (Mor. 10514) — odpowiedzialność z tytułu spuilzie spadła na właściciela nieruchomości, który objął w posiadanie konia pasącego się na jego gruncie i zamiast umieścić go w oborze, zaprzągł go do pracy. 
Brak podstawy prawnej w połączeniu z zaborem rzeczy szczególnie często pojawiał się na gruncie postępowania egzekucyjnego. Stair i Bankton stwierdzają, iż dokonanie egzekucji na podstawie wadliwego tytułu egzekucyjnego uchyla spuilzie, lecz nakazuje restytucję ${ }^{92}$. Jeżeli jednak próbowano dokonać zajęcia rzeczy, która nie podlega egzekucji, takie działanie mogło być uznane za spuilzie $e^{93}$.

Jako spuilzie nie traktowano również wejścia w posiadanie rzeczy, którą wcześniej wierzyciel dzierżył na prawach zastawu. Wierzyciel mógł bez użycia przemocy wejść w posiadanie rzeczy (w drodze traditio brevi manu) na podstawie dyspozycji dłużnika, jeśliby ten nie spłacił długu przed upływem pewnej daty ${ }^{94}$.

Jednocześnie nawet $\mathrm{w}$ przypadku istnienia prawidłowej podstawy prawnej, czynności egzekucyjne mogły prowadzić do spuilzie. Działo się tak, gdy zaoferowano sumę odpowiadającą całemu długowi w czasie prowadzenia czynności lub gdy dokonywano czynności w momencie pracy, a przedmiotem egzekucji miały stać się narzędzia pracy lub zwierzęta do niej wykorzystywane, mimo że inne

92 Autorzy zaznaczają zgodnie, iż ten wyjątek nie dotyczył przypadku, gdy strona działała w złej wierze, czyli wiedziała o wadliwości np. w sytuacji, gdy już po wydaniu rozstrzygnięcia doszło do spłacenia długu lub gdy strona wiedziała o uchyleniu podstawy tytułu egzekucyjnego. Stair 1.9.21. „The third Exception against Spuilzie is, that Goods Libelled were lawfully poynded, for though the Decreet whereupon the poynding was raised should be reduced for want of formality, yet it will not be Spuilzie unless it proceed male fide or ipreta authoritate iudicis, as when the Debt contained in the Decreet, was fully satisfied before poynding”. Bankton 1.9.135. „Lawful poinding will elide spuilie likewise, even tho the decree whereupon it proceeded be afterwards reduced, and the goods thereby come to be restored; but the defence of Lawfully poinded will not take place, if it was used mala fide, after debt contained in the decree was fully satisfied or if the decree was pronounced in contempt the lords of session's authority, after advocation intimated to the party, tho' refused by the judge". Przykład rozstrzygnięcia, w którym pociągnięto do odpowiedzialności z tytułu spuilzie urzędnika, który zajął krowę mimo przedstawienia całej sumy długu do spłaty, ukazuje wyrok Sądu Sesji z dnia 12 grudnia 1620 roku w sprawie Herdman v. Wallwood (Mor 10507).

93 Stair 1.9.22. „The third and most ordinar Reply against Poynidng is that the Goods where not poyndable as being Pleugh Goods, which are not Poyndable the time of Pleughing the Ground". Jako przykład takiego rozstrzygnięcia Stair wskazuje na sprawę Gibson v. Corsbie rozstrzygniętą wyrokiem Sądu Sesji z dnia 1 grudnia 1630 roku (Mor. 10512), w której uznano zajęcie konia pociągowego w trakcie jego pracy jako spuilzie, przy uwzględnieniu istnienia innych rzeczy podlegających egzekucji, które wystarczałyby do zaspokojenia długu.

94 Pisarz kładzie szczególny nacisk na wymóg wejścia w posiadanie bez użycia przemocy taka sytuacja nie mogła być bowiem dopuszczona nawet na podstawie umowy stron, albowiem zgodnie z klasyczną maksymą, prywatne porozumienia nie mogą modyfikować przepisów powszechnie obowiązujących. Bankton 1.9.134. „If one disposes to his creditor certain goods to be intermeddler with breve manu, if debt is not paid at a day prefixed, the creditor may seize goods, upon condition existing without hazard of a spuilzie, but this must be understood of the case, where no violence is used in taking the possession, for otherwise it is a riot, notwithstanding the condition of the agreement, since no person can be warranted, by a private faction, to commit a breach of the peace against the public law, the rule being, the Privatorum conventio juri publico non derogat”. Sędziowie Sądu Sesji oddalili powództwo z tytułu spuilzie w sprawie Dewar v. Murray zakończonej wyrokiem z 19 grudnia 1661 roku (Mor. 1816), albowiem to sam powód przyznał pozwanemu prawo do zabrania zboża w przypadku braku zapłaty czynszu w określonym czasie, co faktycznie miało miejsce. 
przedmioty były wystarczające do zaspokojenia długu ${ }^{95}$. Bankton wskazuje, że owe rozwiązania przyjęto z prawa rzymskiego, jednocześnie jednak zauważa, że przepis całkowicie zabraniający egzekucji takich przedmiotów, gdy dłużnik dysponował nieruchomością, która mogła być sprzedana, jest obecnie nieważny ${ }^{96}$.

Ważny był również sam sposób przeprowadzenia czynności egzekucyjnych — przyjmuje się bowiem, że do spuilzie dochodziło, gdy miały one miejsce przed wschodem słońca lub po jego zachodzie. Działo się tak, dlatego że czynności będące następstwem wykonania wyroku sądowego należało dokonywać w sposób jawny, tak samo jak sprzedaży tych przedmiotów w wyniku licytacji, aby ludzie mogli wziąc udział w ich zakupie ${ }^{97}$.

\section{Zakończenie}

Analiza materiału źródłowego zarówno w formie dzieł instytucjonalnych, jak i orzecznictwa Sądu Sesji nie pozwala wprost odpowiedzieć na postawione we wstępie pytanie o koncepcję posiadania przyjętą w szkockim systemie prawnym. Dzieje się tak, ponieważ choć powszechnie przyjmowano brak konieczności wykazania tytułu prawnego do rzeczy, w znaczącej większości z powództwa tego korzystali właściciele dążący do odzyskania posiadania rzeczy własnej.

Ciekawie również przedstawia się materiał źródłowy z punktu widzenia cezury czasowej — najobszerniejszy bowiem wykład dotyczący instytucji znajdujemy w dziele Banktona z połowy XVIII wieku, w późniejszym zaś dziele Erskine informacje o powództwie są już znacznie bardziej skąpe. Także cytowane orzecznictwo w znakomitej większości dotyczy XVII wieku, wskazując, że to właśnie te

95 Bankton 1.9.136. „But even a poinding for a just debt, upon a regular decree, may turn to a spuilie by the fault of the user. 1 . If the sum poinded for was offered at the time of poinding. 2. If the poinding was in time of labour, and the goods poinded were labouring goods or beast of plough and there were other sufficient goods for the debt upon the ground".

96 Bankton 1.9.137. „We have this regulation from civil law originally, but have varied it much, for that law absolutely prohibited all taking, in execution of debt, labouring slaves, cattle or instruments of labour at any time of the year, and without consideration, whether the debtor had other subject for payment of debt or not. But the case is quite otherwise with us, as above, and if [...] debtor had any lands to be apprised, the poinding the plough goods could be not proceed in time of labour, but this part of statue, as to the lands, is found to be desuetude". W sprawie Turner v. Scot, zakończonej wyrokiem z 7 grudnia 1692 roku (Mor. 10523), sędziowie Sądu Sesji nie uznali za w pełni skuteczną obronę w oparciu o artykuł prawny, który wyszdł z użycia, ale jego wcześniejsze obowiązywanie było wystarczające do doprowadzenia roszczenia jedynie do restytucji posiadania.

97 Bankton 1.9.139. „Lastly, if the poinding was begin before sun-rising or after is setting, it will infer a spuilie, because poinding is a sentence adjudging the property of the goods from the debtor to the creditor, and therefore ought not to proceed clandestinely, and since the goods must be apprised, and set up to roup on the ground, and the market-cross, ket-cross, it ought to be done, when people are presumed to be pretend to bid for them". 
niespokojne czasy poprzedzające powstanie Zjednoczonego Królestwa Wielkiej Brytanii pilnie wymagały reakcji na gwałtowny i bezprawny zabór rzeczy.

Już w drugiej połowie XIX wieku uznawano powództwo z tytułu spuilzie za przestarzałe rozwiązanie prawne i praktycznie zaniechano jego używania ${ }^{98}$. John Townsend wskazuje, że spuilzie nie było podstawą orzeczenia sądowego od 1831 roku, a jako powody takiego stanu rzeczy podaje „ucywilizowanie się"99 szkockiego społeczeństwa, co miało zmniejszać występowanie sytuacji, w których podobna reakcja prawna była konieczna, oraz pewne zatarcie granic między spuilzie a klasycznym powództwem windykacyjnym, co spowodowało, że właściciele chętniej korzystali z drugiej konstrukcji, posiadaczom zaś niebędącym właścicielami zaczęto odmawiać przyznawania tej formy ochrony posesoryjnej ${ }^{100}$.

Brak bezpośredniej abolicji spuilzie jako metody restytucji odebranego siłą posiadania doprowadził do dwóch przeciwnych form reakcji. $Z$ jednej strony istnieją, niestety nieskuteczne, próby odwoływania się do instytucji współcześnie przed Sądami ${ }^{101}$ ), z drugiej strony można wyróżnić głosy prawników pracujących w Szkockiej Komisji Prawnej (Scottish Law Commission), którzy wobec niepewnego zakresu zastosowania instytucji oraz jej nieprzystosowania do współczesnych realiów prawnych i społecznych postulują jej wyraźne uchylenie ${ }^{102}$.

Mimo braku jednoznacznego rozstrzygnięcia pytania badawczego postawionego we wstępie analiza szkockiego powództwa restytucyjnego była dla autora niniejszego opracowania satysfakcjonującym problemem naukowym. Spuilzie może stanowić doskonały przykład rozwiązania prawnego, które czerpiąc z cywilistycznej tradycji prawnej, zostało rozwinięte w wyniku szkockich potrzeb i doświadczeń. Wyjście z użycia powództwa nie było związane z powstaniem systemu hybrydowego i wzrostem wpływu rozwiązań angielskich, lecz naturalnym zanikiem potrzeby restytucji posiadania utraconego w sposób gwałtowny w wyniku postępu cywilizacyjnego. Świadomość istnienia w historii prawa środka reakcji na pozbawienie posiadania w sposób gwałtowny powinna z jednej strony trwać, ponieważ pokazuje bogactwo rozwiązań prawnych, z drugiej zaś należy mieć nadzieję, że nie zaistnieją przyczyny do przywracania podobnej instytucji.

98 J. Chisholm, op. cit., s. 390.

99 Kenneth Reid stwierdza, że współcześnie znacznie częściej poszkodowany ucieka się do zawiadomienia odpowiednich służb lub też do ograniczenia swoich strat w przypadku posiadania ubezpieczenia niż do bezpośrednich prób dochodzenia odszkodowania od sprawcy w ramach postępowania cywilnego. K.G.C. Reid, Property Law..., s. 213.

100 J. Townsend, Raising Lazarus: Why Spuilzie Should be Resurrected, „Aberdeen Student Law Review" 22, 2011, s. 25.

101 Tutaj warto wskazać przede wszystkim sprawę przeciwko instytucjom finansowym Mercantile Credit Co. v Townsley z 1971 roku.

102 Scottish Law Commission, [w:] Corporeal Moveables: Remedies (Memorandum No. 31, Edinburgh 1976), s. 19. 


\section{Bibliografia}

\section{Teksty źródłowe i źródła prawa}

Bürgerliches Gesetzbuch z 24 sierpnia 1896 roku, http://www.gesetze-im-internet.de/bgb/ (dostęp: 2 lipca 2018).

Code Civil des Français z 21 marca 1804 roku, https://www.legifrance.gouv.fr (dostęp: 2 lipca 2018). Darlymple J., viscount of Stair, Institutions of the Law of Scotland, Edinburgh 1681.

Decretum Magistri Gratiani, red. E. Friedberg, Leipzig 1879.

Erskine J., The Institute of the Law of Scotland, Edinburgh 1773.

Macdouall A., Bankton L., Institutes of the Law of Scotland in Civil Rights, Edinburgh 1751-1753. Scottish Law Commission, Corporeal Moveables: Remedies - Memorandum No. 31, Edinburgh 1976.

\section{Wyroki Sądu Sesji}

Scot v. Burlie, 20 lutego 1528 roku (Mor. 14758).

Jardine v. Lady Melgum, 20 marca 1573 roku (Mor. 9359).

Bailie v. Lord Torpichen, 10 stycznia 1611 roku (Mor. 14747).

Douglas v. Young, 17 czerwca 1613 roku (Mor. 14736).

Herdman v. Wallwood, 12 grudnia 1620 roku (Mor 10507).

Russel v. Kerse, 26 lipca 1626 roku (Mor. 14733).

Hay v. Ker, 16 marca 1627 roku (Mor. 11069).

Scot v. Banks, 2 lutego 1628 roku (Mor. 6015).

Brown v. Murray, 8 marca 1628 roku (Mor. 9361).

Gibson v. Corsbie, 1 grudnia 1630 roku (Mor. 10512).

Kirkwood v. Ferguson, 19 lipca 1633 roku (Mor. 2117).

M'Kay v. Menzies, 14 marca 1635 roku (Mor. 14749).

Dewar v. Murray, 19 grudnia 1661 roku (Mor. 1816).

Irving v. M'Kartney, 30 stycznia 1662 roku (Mor. 14750).

Berfoord v. Kingstoun, 27 stycznia 1665 roku (Mor. 1817).

Lord Justice Clerk v. Home of Linthel, 28 lutego 1668 roku (Mor. 13985).

Duncan v. Kids, 10 lutego 1676 roku (Mor. 10514).

Maxwel v. Maxwel, 27 lipca 1676 roku (Mor. 14729).

Hay v. Leonard, 21 listopada 1677 roku (Mor. 10286).

Gordon \& Robertson v. Menzies, 11 czerwca 1680 roku (Mor. 1680).

Thin v. Langshaw, listopad 1683 roku (Mor. 14753).

Strachan v. Morison, styczeń 1687 roku ( Mor. 14710).

Turner v. Scot, 7 grudnia 1692 roku (Mor. 10523).

Fea v. Elphiston, 2 stycznia 1697 roku (Mor. 9367).

Ker v. Dunbar, 5 lutego 1706 roku (Mor. 16460).

Lewars v. Carmichael, 5 czerwca 1711 roku (Mor. 10348).

Currie v. Crawford, 24 czerwca 1745 roku (Mor. 6206). 


\section{Literatura}

Bell W., A Dictionary and Digest of the Law of Scotland, Edinburgh 1838.

Berger A., Encyclopedic Dictionary of Roman Law, Philadelphia 1953.

Cairns J.W., Institutional Writings in Scotland Reconsidered, [w:] New Perspectives in Scottish Legal

History, red. A. Kiralfy, H.L. MacQueen, London 1984.

Carrey Miller D.L., Corporeal Moveables in Scots Law, Edinburgh 1991.

Caterina R., Concepts and remedies in the law of possession, „Edinburgh Law Review” 8, 2004.

Chisholm J., Green's Encyclopaedia of the law of Scotland, t. 11, Edinburgh 1899.

Luig L., The Institutes of National Law in the Seventeenth and Eighteenth Centuries, „Juridical Review" 17, 1972.

Morrison W.M., The Decision of the Court of Session, from its Institutions to the Present, in the Form of Dictionary, t. 1-21, Edinburgh 1801-1808.

Reid D., Thomas Aquinas and Viscount of Stair: the Influence of Scholastic Moral Theology on Stair's Account of Restitution and Recompense, „Journal of Legal History” 29, 2008.

Reid K.G.C., The Law of Property in Scotland, Edinburgh 1996.

Reid K.G.C., Property Law: Sources and Doctrine, [w:] A History of Private Law in Scotland, red. K.G.C. Reid, R. Zimmermann, Oxford 2000.

Townsend T., Raising Lazarus: Why Spuilzie Should be Resurrected, „Aberdeen Student Law Review" 22, 2011.

Yiannopoulos A.N., Possession, „Louisana Law Review” 51, 1991.

\section{Spoliatus ante omnia restituendus est. Spuilzie as a Scottish method of restitution of lost property}

Summary

The author of the study tries to answer the question about the theory of the nature of possession in Scottish jurisprudence on the basis of the existing model of possessory protection. To this end he analyses spuilzie - a Scottish remedy to seek restitution, popular especially in the 17th and 18th centuries.

He presents the views of the most important Scottish jurists, regarded as institutional writers of the day: James Dalrymple, Viscount of Stair; Andrew MacDougall, Lord Bankton; and John Erskine of Carnock. In addition, he presents the case law of Scotland's Supreme Court (Court of Session) concerning the subject matter in question.

The problems analysed by the author are as follows: the origins and ways of defining the legal basis of the remedy, its legal nature, capacity to sue, separate procedures and forms of defence employed by the sued party in spuilzie cases.

Keywords: spuilzie, possession, property law, possessory protection, Scots law, institutional writers, hybrid legal systems 


\section{Spoliatus ante omnia restituendes est. Spuilzie als schottische Methode der Restitution des entgangenen Besitzes}

\section{Zusammenfassung}

In der Bearbeitung wurde versucht, die Frage nach der führenden Theorie in der schottischen Rechtslehre für die Entscheidung über die Natur des Besitzes, gestützt auf das geltende Modell des possessorischen Schutzes, zu beantworten. Zu diesem Ziel wurde die spuilzie - schottische Restitutionsklage analysiert, die besonders populär im 17. und 18. Jahrhundert gewesen ist.

In dem Aufsatz wurden die Ansichten der führenden Rechtsautoritäten präsentièrt. Gemeint sind hier die als institutionelle Schreiber (institutional writers) anerkannten: der Viscount von Stair — James Dalrymple, der Lord Bankton - Andrew MacDouall sowie John Erskine aus Carnock. Es wurde auch die führende Rechtsprechung des schottischen Obersten Gerichtes (Sessionsgericht) in diesem Bereich vorgestellt.

Die Erwägungen wurden aufgrund folgender Problematik geführt: Genesis und Art der Definierung der rechtlichen Grundlagen der Klage und ihres rechtlichen Charakters, der Klagebefugnis, der im Rahmen der Verfahren wegen spuilzie bestehender Verfahrensbesonderheiten und der durch den Beklagten präsentierten Verteidigungsformen.

Schlüsselworte: spuilzie, Besitz, Sachenrecht, possessorischer Schutz, schottisches Recht, institutionelle Schreiber, hybride Rechtssysteme 